\title{
HYALINOTHRIX, A NEW GENUS OF STARFISHES FROM THE HAWAIIAN ISLANDS.
}

\author{
By Walter K. Fisher, \\ Of Stanford University, California.
}

The type of the new genus and species herein described was collected in 1902 by the U. S. Fisheries steamer Albatross, near the island of Molokai, Hawaiian Islands. The two specimens were received after the publication of my report on the starfishes of the Hawaiian Islands.

Hyalinothrix superficially resembles two genera, which are not commonly considered closely related, namely Chxtaster and Nepanthia. The resemblance to Chrtaster is chiefly in the character of the spinelets, in the tabulate abactinal plates, and in the form and armature of the adambulacral and mouth plates. The most important differences between the two genera are listed below in parallel columns.

\section{Hyalinothrix.}

Abactinal plates with four or five lobes which overlap those of neighboring plates; no internal independent connecting ossicles.

Abactinal plates in quincunx only on dorsolateral region of ray, and there in more evident oblique and straight transverse than in direct longitudinal series; median radial plates more or less irregular; abactinal plates in about forty longitudinal series.

Spinelets conspicuously longer than height of tabulum, extremely delicate and glassy.

Marginal plates very small; an odd interradial marginal probably absent.

Superambulacral plates absent. Ampullæ of tube feet incipiently two-lobed, wider than high.

Disk moderately small; rays tapering from swollen base.

\section{Chætaster.}

Abactinal plates with six very short lobes which do not appreciably overlap those of neighboring plates; four internal independent ossicles present, binding together the plates of adjacent longitudinal series.

Abactinal plates arranged in quincunx in nine very regular longitudinal series, the median radial plates the largest.

Spinelets not longer than height of tabulum and only moderately delicate.

Marginal plates conspicuous; an odd interradial marginal present.

Superambulacral plates present. Ampullæ of tube feet single, higher than wide.

Disk very small; rays very slender and finger like. 
Gray included two species in his genus Nepanthia, 1840-tessellata (=Chxtaster longipes), and maculata. No type was indicated; maculata, the only available species, is therefore the type. This species has rather long slender rays, and is of the general habit of Chætaster longipes. $^{a}$ I have examined a closely related form from the Philippines. The spinelets, though very short, are delicate, and are distally clear and glassy. The middorsal area of externally crescentiform pseudopaxillæ is clearly distinguishable from the several dorsolateral longitudinal series of squarish or roundish pseudopaxillæ. Internally both sorts of plates are lobed and imbricated. The crescentic appearance of the plates externally is due to the fact that, being arranged in quincunx, two lobes of a plate overlap the abcentral side of the next two plates toward center of disk. In the interval between the lobes the papulæ emerge, and the exposed surface has a crescentiform cluster of minute spinelets. The abactinal plates of Hyalinothrix imbricate in the same fundamental manner, but the plates of the radial regions have five lobes, so that in overlapping they frequently but not always join three plates adcentrally. In Hyalinothrix the actinal intermediate plates imbricate to form chevrons, or both longitudinal and transverse series, and the adambulacral spinelets are basally webbed, though not forming fans in the actinal series as in Nepanthia. But the presence of well-developed tabula on the plates of Hyalinothrix excludes the genus from the Asterinidæ (restricted), where the abactinal plates are essentially lamelliform and notched on the adcentral side.

Neither does it seem possible to place Hyalinothrix in the Chætasteridæ of Ludwig, for the resemblances are only superficial and are outweighed by the differences, namely, the small marginal plates, no odd interradial marginals, absence of superambulacrals, the more numerous and fundamentally different abactinal plates which lack internal connecting ossicles, the incipiently bilobed ampullæ.

The Ganeriidæ have lobed paxilliform plates and small marginals, and the actinal intermediate plates in series extending from the adambulacrals to the marginals. Hyalinothrix, although quite different from Ganeria, Cycethra, Radiaster, and Scotiaster, appears to belong in this group. Eventually, when the anatomy of the above genera is known, it may be advisable to segregate Hyalinothrix in a special subfamily, the Hyalinothricinæ.

HYALINOTHRIX, new genus.

Type--Hyalinothrix millespina, new species.

Stellate, with rounded rays. Marginal plates very small. All plates more or less tabulate, the abactinals strongly four or five lobed, and imbricating by the lobes; abactinal plates numerous, irregularly 
arranged along median radial areas but in regular oblique and crosswise series on dorsolateral portions of ray; tabula of plates surmounted by a dense brush of very many extremely delicate sharp glassy hairlike spinelets. Papulæ in four or five areas about each abactinal plate; one or two papulæ to an area. Adambulacral plates squarish, with three or four furrow spinelets basally webbed and very numerous, smaller, actinal spinelets. Actinal interradial areas small, the plates in three to five rows, with a central convexity or tabulum, and strongly imbricated in chevrons. Superambulacral plates absent; anus present; gonads interradial; tube feet in two series with sucking disks, without deposits; ampullæ incipiently bilobed; interbrachial septa calcified.

\section{HYALINOTHRIX MILLESPINA, new species.}

Diagnosis.-Rays 5; $\mathrm{R}=45$ to $50 \mathrm{~mm}$., $\mathrm{r}=10$ to $11 \mathrm{~mm}$.; $\mathrm{R}=4$ to $5 \mathrm{r}$; breadth of ray at widest part $13 \mathrm{~mm}$. Disk small; rays well arched abactinally, subplane actinally, bluntly pointed and slightly constricted at base. Abactinal plates four or five lobed, with low tabula bearing 75 to 100 very slender clear spicules, which give the appearance of the pile or nap of plush; papulæ one or two to an area, usually four areas about each plate; marginal plates only slightly larger than adjacent abactinals; proximally three or four regular series of actinal intermediate plates, distally only one. Adambulacral plates with three or four furrow spinelets in a straight series, and on actinal surface a dense squarish or roundish paxilliform group of numerous slender spinelets.

Description.-The skeleton is in the form of irregularly four or five lobed tabulate plates, which overlap by the lobes, leaving irregular papular areas smaller than the plates and containing usually single papulæ. On the midradial area and center of disk the plates are not regularly arranged, but on the sides of the rays they are in pretty regular quincunx as far as the superomarginal series, being arranged in straight as well as oblique transverse series; and on some rays near the base, on either side of the midradial area, a less regular arrangement in longitudinal lines is observable. Each plate is raised into a low convex tabulum equal to or lower than its width at top, surmounted by a dense brush or group of very numerous and diverging delicate spicules. These spicules or spinelets are more delicate and slender than any to be found elsewhere in the Asteroidea. They vary in length from $0.75 \mathrm{~mm}$. to $0.975 \mathrm{~mm}$., and the articulating base is about $0.06 \mathrm{~mm}$. thick, and thence tapers toward the tip, near which the spinelet is $0.0155 \mathrm{~mm}$. thick. The distal three-fourths or fourfifths of each spicule is clear and glassy, only the basal part being reticulated, or perforated, in the characteristic way. The epidermis 
seems to be lacking except on the basal portion of each spinelet. Some of the spicules are forked near the base, the two branches being unequal. The spinelets are longer than the height of tabulum, and owing to their extreme tenuity are well preserved abactinally only in the interradial sulcuses. Over most of the abactinal surface the distal part of the spinelets is broken off. On the interradii where the spinelets are well preserved those of neighboring paxillæ touch across the interspaces, and each group is distally slightly convex. There are between seventy-five and one hundred spinelets to an average sized paxilla, and the paxillæ decrease in size toward the end of ray and laterally toward the marginal plates.

The papulæ are distributed all over the abactinal surface, except at the very tip of ray, and laterally as far as the superomarginal plates. Each plate is surrounded by four papulæ except on the midradial area, where there are sometimes five papular areas around each paxilla, and often there are two papulæ to an area.

On the actinal surface of the distal half of each ray are three series of paxilliform plates, slightly lower and larger than the lateral paxillæ of abactinal surface, arranged parallel to the still larger squarish adambulacrals. The outer two, which are the marginals, toward the base of ray diverge from the inner (which is the first actinal intermediate series and reaches very nearly to tip of ray) and at the interradial line are nearly on the ambitus, being separated from the adambulacrals by about four longitudinal series of actinal intermediate plates. These marginal plates are very small, and the inferomarginal series is slightly the more regular of the two. The plates of the two series are subequal and a trifle larger than adjacent abactinals. The plates are so small that it is not possible to ascertain if an odd interradial plate is surely absent; from a study of the arrangement of adjacent actinal intermediate plates, I think they are. In one or two interradii, however, it is difficult to be sure, as the plates are pushed out of position.

As mentioned above, one series of actinal intermediate plates nearly reaches tip of ray, the second row reaches about two-fifths length of ray measured along side (or about one-half $R$ ), while the third and fourth rows contain only a few plates and extend but a short distance; a few plates of a fifth row are present in two interradii. It is the interpolation of these three extra rows of intermediate plates which causes the marginals to be crowded toward the ambitus. Spinelets of actinal intermediate plates are about $0.675 \mathrm{~mm}$. in length and are perforated to the tip, which commonly ends in two or three short, sharp, glassy prongs. The intermediate plates have prominent convex tabula and overlap plates of both their own and adjacent series. The free edge of the plate is toward the furrow and interradial lines. 
Adambulacral plates nearly square, slightly larger than adjacent actinal intermediate plates. The actinal surface is slightly raised for the articulation of a roundish or squarish paxilliform group of numerous delicate spinelets which increase in thickness, but not in length, toward the furrow. The furrow series consists of three or four still longer basally webbed spinelets, which reach nearly across the narrow groove and which are slightly longer than width of plate. The central one or two of these spinelets is slightly the longest. The outer subambulacral spinelets are similar in character to the actinal intermediate spinelets, except that the two or three prongs are longer, the whole spinelet being about $0.75 \mathrm{~mm}$. long. Toward the furrow, however, the spinelets become thicker and end in five or six short thorns, and the shaft is perforated by several longitudinal series of pores, forming the characteristic reticulum; only the little prongs are clear. In contrast to the abactinal spicules these spinelets are 0.1 $\mathrm{mm}$. thick at base and $0.06 \mathrm{~mm}$. at tip. The subambulacral spinelets on at least two series adjacent to furrow are basally webbed.

Mouth plates with a dense triangular group of numerous spinelets on actinal surface, the two groups on companion plates being separated by a prominent median suture. Marginal spinelets about seven, similar to those of adambulacral plates.

Madreporic body small, nearly hidden by overlapping paxillæ; striæ coarse and irregular. Anal aperture, subcentral.

Color in alcohol, bleached yellowish brown.

Anatomical notes.-Tube feet with strong sucking disks; no deposits. Ampullæ single, incipiently two-lobed. Gonads interradial. Interbrachial septa strongly calcified. Integumentary layer beneath plates, thick and tough. No superambulacral plates present, the lower end of each ambulacral ossicle being, instead, produced into a short lobe. Strong retractors of stomach present.

Variations.-The cotype has somewhat slenderer rays. The marginal plates do not form quite such regular series as in the type, and there are much fewer actinal intermediate plates. The series adjacent to the adambulacral plates extends only half the length of ray or even less; the second series is one-third as long as the first; the third, very short (only about half a dozen plates); the fourth is either absent or represented by only two or three plates; in one interradius the fifth is just starting (one or two plates).

Type.-Cat. No. 27674, U. S. N. M.

Type-locality.-Albatross station 3863, Pailolo Channel, between Molokai and Maui Islands, Hawaiian Islands, 127 to 154 fathoms, broken coral, coarse gravel, rocks; two specimens. 


\section{EXPLANATION OF PLATES.}

\section{(All plates represent Hyalinothrix millespina.)}

Plate 69.

Abactinal view of type, enlarged about $2 \frac{1}{2}$ times.

\section{Plate 70.}

A portion of actinal surface of type enlarged; int, actinal intermediate plates; $1-5$, the five series of actinal intermediate plates. The three plates of the fifth series are marked with white spots, there being an unpaired plate, and one to each ray; inf, inferomarginal, and sup, superomarginal plates. Between the two white lines indicating these plates are seen the first superomarginals of each ray. The lines in both cases point to the second plate of the series.

\section{Plate 71.}

Fig. 1. Abactinal plate from near base of ray, side view; $\times 30$. This is to give an idea of the relative size of tabulum and spinelets; not all the latter are shown, and most of these are represented somewhat too stout.

2. Spinelets from abactinal plates; $\times 70$.

3 . The base and tip of a spinelet; $\times 250$.

4. Abactinal plates from near base of ray and border of midradial area, seen from outside to show the tabula and papular areas, in which the one or two papulæ are not indicated; $\times 10$.

5. Abactinal plates from near base of ray and adjacent portion of disk, seen from inside; $\times 10$. The plates to right are those of the radial area, those to the left showing the more regular arrangement of the dorsolaterals. Papular areas shaded; $s$, position of interbrachial septum.

6. An adambulacral plate from proximal half of ray; $\times 10$. Not all the subambulacral spinelets can be shown.

7. Three ambulacral plates from near base of ray to show the lobes at lower end over-lapping the suture between the adambulacral plates; $\times 10$. 


\section{$2 \mathrm{BHL}$ Biodiversity Heritage Library}

Fisher, Walter K. 1911. "Hyalinothrix, a new genus of starfishes from the Hawaiian Islands." Proceedings of the United States National Museum 39(1807), 659-664. https://doi.org/10.5479/si.00963801.39-1807.659.

View This Item Online: https://www.biodiversitylibrary.org/item/53443

DOI: https://doi.org/10.5479/si.00963801.39-1807.659

Permalink: https://www.biodiversitylibrary.org/partpdf/51999

\section{Holding Institution}

Smithsonian Libraries

\section{Sponsored by}

Smithsonian

\section{Copyright \& Reuse}

Copyright Status: Public domain. The BHL considers that this work is no longer under copyright protection.

This document was created from content at the Biodiversity Heritage Library, the world's largest open access digital library for biodiversity literature and archives. Visit BHL at https://www.biodiversitylibrary.org. 